\title{
Sex steroid hormones in serum and tissue of benign and malignant breast tumor patients
}

\author{
Essam A. Madya,b,*, \\ Ezz El-Din H. Ramadan ${ }^{\mathrm{b}}$ and Alaa A. Ossman ${ }^{\mathrm{c}}$ \\ ${ }^{a}$ Department of Biochemistry, Faculty of Science, Ain \\ Shams University, Cairo, Egypt \\ ${ }^{\mathrm{b}}$ Oncology Diagnostic Unit, Faculty of Medicine, Ain \\ Shams University, Cairo, Egypt \\ ${ }^{\mathrm{c}}$ Department of Surgery, Faculty of Medicine, Ain \\ Shams University, Cairo, Egypt
}

Received 4 May 2000

Accepted 1 October 2000

The ability of breast tumors to synthesize sex steroid hormones is well recognized and their local production is thought to play a role in breast cancer development and growth. The aim of this study was to estimate local intra-tumoral and circulating levels of Estrone $\left(E_{1}\right)$, Estrone Sulfate $\left(E_{1} S\right)$, Estradiol $\left(\mathrm{E}_{2}\right)$, Estriol $\left(\mathrm{E}_{3}\right)$, and Testosterone $(\mathrm{T})$ in 33 pre- and postmenopausal women with primary breast cancer in comparison to 12 pre- and postmenopausal women with benign breast tumors. The mean levels of the studied sex hormones were higher in serum and tumor tissue of breast cancer women than those with benign breast tumors apart from Testosterone which showed a significant decrease in pre- and postmenopausal women with breast cancer $(P<0.001$ for follicular phase, $P<0.05$ for luteal phase, and $P<0.005$ for postmenopausal). The levels of the five hormones were significantly higher intra-tumoral than in serum of both benign and malignant breast tumor women with $\mathrm{E}_{1} \mathrm{~S}$ as the predominant estrogen. There was only a positive significant correlation between serum and tumor tissue levels of $\mathrm{E}_{1}$ ( $r s=0.52, P<0.05$ for follicular; $r s=0.63, P<0.05$ for luteal and $r s=0.58, P<0.05$ for postmenopausal) and a significant correlation between serum and tumor tissue of $\mathrm{T}(r s=0.64, P<0.05$ for follicular; $r s=-0.51, P<0.05$ for luteal and $r s=-0.81, P<0.04$ for postmenopausal).

Keywords: Menopause, breast cancer, estrone, estrone sulfate, estradiol, estriol, and testosterone

*Present address: Chemistry Dept., Faculty of Education, King Faisal University, P.O.Box 1759, Al-Hassa 31982, Saudi Arabia.

\section{Introduction}

Tumors derived from a hormonal target organ are assumed to be stimulated by the same hormone that stimulates the normal target tissue [1]. Sex steroid hormones play a major role in the etiology of several of the commonest cancers worldwide, including cancers of the endometrium, breast and ovary in women [2]. Adipose tissue is the site of uptake, storage and metabolism of sex steroids. After menopause, aromatization of androgens to estrogens in adipose tissue is one of the most important sources of estrogens in the circulation and for peripheral tissue $[3,4]$.

Clinical and experimental observations of breast cancer are indicative of a disease with a complex biology and a clinical outcome that varies greatly, even in patients with similar pathologic features [5]. In vivo proliferation of normal breast epithelial cells is higher during the luteal phase in the vast majority of women. From a hormonal point of view, several previous studies suggested that some benign breast diseases and breast cancer may share common epidemiological facts or even represent different stages of one process. Normal breast tissue can convert estrone sulfate to estradiol. A negative correlation between the levels of circulating estradiol and the enzyme converting estrone to estradiol suggests a local regulatory mechanism of tissue estradiol formation [6]. Grattorola et al. [7] were the first to suggest a possible role of androgens in the development of breast cancer in postmenopausal women. Androgens may act directly, by stimulating breast cell proliferation through binding to androgen receptors or by stimulating the synthesis of growth factors inside the breast epithelium [8,9]. Androgens may also act indirectly through their conversion to estrogens, which are known to stimulate breast cell proliferation [10,11]. Aromatization of testosterone and androstenedione via aromatase in the peripheral tissue may have a great quantitative contribution to the formation of estrogens. In addition, it is well established that testosterone binds to sex hormone-binding globulin (SHBG) with great affinity than estradiol. Testosterone may thus indirectly 
increase the risk of breast cancer by decreasing the fraction of estradiol bound to SHBG and thereby increasing the unbound fraction, which is thought to be the fraction available to breast cancer [12-14]. However, it is not clear at present what is the quantitative contribution of androgens via aromatase to the formation of estrogens, because more recently it was found that estradiol in breast cancer tissues originates mainly via sulfatase using estrone sulfate as precursor. Also, it has been suggested that testosterone inhibits hepatic secretion of SHBG which could result in a decreased fraction of estradiol bound to SHBG [15]. Dorgan et al. [16] lend considerable support to the hypothesis that serum concentrations of estrogens and androgens are related to the subsequent diagnosis of breast cancer in postmenopausal women. However, it was suggested that increased levels of testosterone might have a modest but indirect association with breast cancer through its conversion to estradiol [17]. Estrone sulfate is the most abundant circulating estrogen in postmenopausal women and a major component of some postmenopausal hormone preparation and it has been hypothesized to be an important source of estradiol in normal breast tissues and breast cancer cells $[18,19]$. Cauly et al. [20] suggested that estradiol and testosterone levels may play important roles in the development of breast cancer in older women. A single measurement of bioavailable estradiol and free testosterone may be used to estimate a woman's risk for breast cancer. Berrino et al. [21] supported the positive association between elevated estrogen level and breast cancer and they additionally suggested that raised serum testosterone levels precede breast cancer occurrence.

We report here the relationship between serum and tissue levels of estrone, estrone sulfate, estradiol, estriol and testosterone in pre- and postmenopausal patients with benign and malignant breast tumors. A specific objective of this study was to examine the differential distribution levels of these five hormones between serum and tumor tissues.

\section{Materials and methods}

\subsection{Subjects}

This study was carried out on 33 women with primary localized breast cancer and 12 women with benign breast tumors. All the patients were admitted to the Department of Surgery, Ain Shams University Hospitals and the National Cancer Institute, Cairo Univer- sity during the period from May 1997 to March 1998. The age, menopausal status and clinical data of all patients included in this study are shown in Tables 1 and 2.

Women were defined as postmenopausal if they reported having a natural menopause or a bilateral oopherectomy. Women who had received hormonal treatment in the 6 months prior to enrollment, who had bilateral ovariectomy or who had a history of cancer or liver disease were not recruited.

\subsection{Blood sampling}

Preoperative fasting blood samples were drawn from all patients. After centrifugation, serum samples were separated, aliquoted and immediately stored at $-80^{\circ} \mathrm{C}$ for subsequent biochemical analyses.

\subsection{Tissue collection and cytosol preparation}

Breast tumor tissue samples were obtained at the operating theatre directly after removal of the tumor mass. Tissue samples were transported to the laboratory in liquid nitrogen, dissected away from necrotic tissues, then washed with cold saline, cut into small pieces and frozen immediately in liquid nitrogen and stored at $-120^{\circ} \mathrm{C}$ until processed for preparation of cytosol fractions.

Cytosolic fractions were prepared from tumor tissue samples according to the method of Grimaux et al. [22]. Briefly, tissues were minced and homogenized in $(10 \mathrm{ml} / \mathrm{g}$ tissue) ice-cold homogenization buffer $(10 \mathrm{ml}$ Tris $\mathrm{HCl}, 10 \mathrm{ml}$ sodium molybdate, $0.4 \mathrm{M} \mathrm{KCl}$, $10 \% \mathrm{w} / \mathrm{v}$ glycerol and dithiotreitol, PH 7.6). The homogenate was then centrifuged for 1 hour at 105000 $\mathrm{x} \mathrm{g}$ at $2{ }^{\circ} \mathrm{C}$. the resultant supernatant which represents the cytosolic fraction was subdivided into aliquots and stored at $-120^{\circ} \mathrm{C}$ till the hormonal assays.

\subsection{Laboratory analyses}

Serum samples and cytosolic fractions of all benign and malignant breast tumor patients were saved for the assay of Estrone $\left(E_{1}\right)$, Estrone Sulfate $\left(E_{1} S\right)$, Estradiol $\left(\mathrm{E}_{2}\right)$, Estriol $\left(\mathrm{E}_{3}\right)$, and Testosterone $(\mathrm{T})$.

Estrone $\left(\mathrm{E}_{1}\right)$ was determined using radio-immunoassay (RIA) kit DSL8700 supplied by Diagnostic System Laboratories, USA; Estrone Sulfate $\left(\mathrm{E}_{1} \mathrm{~S}\right)$ was determined using a radio-immunoassay (RIA) kit DSL5500 supplied by Diagnostic System Laboratories, USA: Estradiol $\left(\mathrm{E}_{2}\right)$ was determined using ELIZA Fertigenix 
Table 1

Age and menopausal status of benign and malignant breast tumor patients

\begin{tabular}{lcccccc}
\hline Variable & \multicolumn{2}{c}{$\begin{array}{c}\text { Benign group } \\
(N=12)\end{array}$} & & & \multicolumn{2}{c}{$\begin{array}{c}\text { Malignant group } \\
(N=33)\end{array}$} \\
\cline { 2 - 3 } \cline { 5 - 6 } \cline { 5 - 6 } & $\mathrm{N}$ & Mean $\pm \mathrm{SE}$ & & $\mathrm{N}$ & Mean $\pm \mathrm{SE}$ \\
\hline Age & & & & & \\
Premenopuasal & 6 & $29.5 \pm 5$ & & 16 & $37 \pm 0.9$ \\
Follicular phase & 3 & $33 \pm 2.4$ & & 9 & $39 \pm 0.5$ \\
Luteal phase & 3 & $26 \pm 0.8$ & & 7 & & $36 \pm 1.3$ \\
Postmenopausal & 6 & $49 \pm 0.8$ & & 17 & & $57 \pm 0.4$ \\
\hline
\end{tabular}

Table 2

Clinical data of patients with benign and malignant breast tumors

\begin{tabular}{lr}
\hline Variable & No. \\
\hline Benign cases & 2 \\
Isolated cysts & 3 \\
Fibrocystic diseases & 4 \\
Fibroadenoma & 2 \\
Lobular hyperplasia & 1 \\
Increased nodularity of both breast & \\
Malignant cases & \\
Histologic type & 25 \\
Invasive ductal carcinoma & 6 \\
Infiltrative ductal carcinoma & 2 \\
Lobular carcinoma & \\
Grade & 29 \\
II & 4 \\
III & \\
Stage & 19 \\
II & 14 \\
III
\end{tabular}

kit supplied by Biosource, Europe SA; Estriol $\left(\mathrm{E}_{3}\right)$ was determined using ELIZA kit DSL10-4000 supplied by Diagnostic System Laboratories, USA; and Testosterone (T) was determined using ELIZA kit supplied by Diagnostic System Laboratories, USA.

Before assaying the particular hormone in cytosolic samples, each kit was subjected to a systematic reliability protocol including linearity, recovery, reproducibility, inter-assay, and intra-assay ( data not shown).

The results obtained were statistically analyzed using SPSS package (Echo Soft Corp., USA, 1993).

\section{Results}

As shown in Table 1, this study was carried out on 33 women with primary breast cancer. 16 were premenopausal 9 were in the follicular phase and 7 in the luteal phase of the menstrual cycle at the time of sampling, and 17 were postmenopausal.

They were 25 cases with invasive ductal carcinoma, 6 with infilterative ductal carcinoma and 2 with lob- ular carcinoma (Table 2). This group of cancer patients was studied in comparison to a control group of 12 women (6 premenopausal and 6 postmenopausal) suffering from different benign breast lesions.

Regarding the serum levels of $E_{1}$, it was significantly increased in both phases (follicular and luteal) of premenopausal women with malignant breast tumors compared to their corresponding controls $(P<0.05)$. However, the increase in $\mathrm{E}_{1}$ levels in serum of postmenopausal breast tumor women compared to those with benign disease was non- significant (Table 3 ).

The same pattern was noted in the serum levels of $E_{2}$ as it was significantly increased in both subgroups of premenopausal women with malignant breast tumors compared to those with benign breast disease $(P<$ 0.05 ) but there was no significant difference between the postmenopausal groups.

The behavior of $\mathrm{E}_{1} \mathrm{~S}$ in serum was exactly opposite to that of both $E_{1}$ and $E_{2}$. The only significant difference was between the two groups of postmenopausal women. Serum $\mathrm{E}_{1} \mathrm{~S}$ showed a decrease in postmenopausal women with malignant breast tumors compared to those with benign breast tumors $(P<0.02)$ without any significant difference was found among the premenopausal groups.

Estriol $\left(E_{3}\right)$ was only significantly increased during the luteal phase in women with malignant breast tumors than their corresponding women with benign breast tumors $(P<0.05)$.

Remarkably, over all the three different populations, Testosterone (T) showed a highly significant decrease in women with malignant breast tumors $(P<0.001$ for follicular; $P<0.05$ for luteal and $P<0.005$ for postmenopausal respectively) (Table 3 ).

Regarding the cytosolic levels of all the five studied hormones, they showed non-significant differences among premenopausal women with benign and malignant breast tumors apart from the highly significant increase in both $\mathrm{E}_{1}$ and $\mathrm{T}$ among postmenopausal women with malignant breast tumors $(P<0.005)$. Cytosolic $\mathrm{E}_{3}$ was the only hormone that showed a significant decrease in postmenopausal women with malignant breast tumors $(P<0.05)$ (Table 4).

The differential expression of both $\mathrm{E}_{1}$ and $\mathrm{E}_{2}$ in serum of benign and malignant patients was highly positively correlated as the Pearson correlation coefficient was $0.78(P<0.04)$ in follicular; $0.72(P<0.04)$ in luteal and $0.67(P<0.05)$ in postmenopausal women respectively. Additionally, this linear positive correlation between $E_{1}$ and $E_{2}$ was negatively correlated with the levels of $\mathrm{T}$ in serum of premenopausal women as 
the Pearson correlation coefficient for $\mathrm{T}$ with $\mathrm{E}_{1}$ and $\mathrm{E}_{2}$ were $-0.65(P<0.05)$ and $-0.72(P<0.04)$ for follicular phase and $-0.88(P<0.004)$ and $-0.79(P<0.04)$ for luteal phase respectively.

Testosterone level showed a significantly positive correlation with $\mathrm{E}_{1} \mathrm{~S}$ in serum of postmenopausal women where the Pearson correlation coefficient was $0.93(P<0.03)$.

The correlation between serum and tissue levels of the five studied hormones has also been calculated. Significant correlations were found between serum and tissue level of $\mathrm{E}_{1}$ ( $\left.r s=0.52, P<0.05\right)$ for follicular; ( $r s=0.63, P<0.05$ ) for luteal and ( $r s=0.58, P<$ $0.05)$ for postmenopausal and a significant correlation between serum and tissue level of $\mathrm{T}$ in postmenopausal women ( $r s=0.64, P<0.05)$ for follicular; $(r s=$ $-0.51, P<0.05)$ for luteal and $(r s=-0.81, P<$ 0.04 ) for postmenopausal respectively.

The present study did not reveal any significant differences in the levels of all the five studied hormones in relation to either the stage or the grade of the tumor.

\section{Discussion}

The results of the present study reveal that there is a remarkable increase in the levels of the four hormones $E_{1}, E_{1} S, E_{2}$, and $E_{3}$ in serum of pre- and postmenopausal women with malignant breast tumors compared to those with benign breast tumors except for the significant decrease in $\mathrm{E}_{1} \mathrm{~S}$ in postmenopausal women. $\mathrm{E}_{1} \mathrm{~S}$ also showed the highest level among the four hormones, particularly in premenopausal women with benign and malignant breast tumors. These findings are strongly supported by several previous studies $[18,19$, 23-29], that reported similar results and accordingly suggested that $\mathrm{E}_{1} \mathrm{~S}$ is the most abundant circulating estrogen in postmenopausal women. $\mathrm{E}_{1} \mathrm{~S}$ could be converted to $E_{1}$ via sulfatase enzyme and $E_{1}$ also could be converted to $E_{2}$. This is supported by the high significant levels of both $E_{1}$ and $E_{2}$ and may lead to the suggestion that sulfatase enzyme activity might be more pronounced in postmenopausal women as the level of $\mathrm{E}_{1} \mathrm{~S}$ was significantly decreased in this population.

The increased level of $E_{2}$ could be also explained according to the paracrine influence of human breast cancer cells as studied by Mehta and Graves [30] who suggested that in breast cancer patients factors produced by malignant tumor mass may have paracrine influence on surrounding non malignant breast tissue, and thereby, may influence estrogen availability to the tumor mass.
The most striking observation is the significant decrease in serum levels of testosterone in pre- and postmenopausal women with malignant breast disease with a corresponding significant increase in estrogens. As testosterone could be converted to estrogens through the enzymatic activity of aromatase, it may have an indirect effect on breast cancer development [10,13,3134]. Our findings concerning the low detected levels of testosterone are not in accordance with other studies which reported high levels of $\mathrm{T}$ in breast cancer patients $[13,20,21,26]$. We could explain this disagreement on the basis that in some of the reported studies breast cancer cases were diagnosed some years after blood sampling, leading to the suggestion that elevated serum levels of $\mathrm{T}$ may precede breast cancer occurrence.

It was previously reported that estrogens and some androgens levels in normal breast tissues are much higher than their levels in serum, and their levels in malignant tissues are higher than those in normal breast tissues. This difference may be due to enzymatic activities in normal and malignant breast cells that result in the local conversion of androgens to estrogens, estrone sulfate to estrone and estrone to estradiol [31,35-38]. These data could support the results in the present study, as the five studied hormones were significantly higher in tumor tissue than serum in both benign and malignant breast tumor women with $\mathrm{E}_{1} \mathrm{~S}$ as a predominant estrogen. However, there was no significant difference between benign and malignant tissues for premenopausal women while the only significant difference appeared among the postmenopausal populations.

The highly significant decrease in cytosolic level of $\mathrm{E}_{3}$ in malignant tissue from postmenopausal women coincided with its significant increased level in serum for this population of patients.

Although several reports $[29,35,36,39,40]$ have indicated that there is a little if any, correlation between serum and tissue steroid levels, these studies contained small case numbers and correlation data were not provided. Given our findings and those of other studies described above, it seems unlikely that they are entirely uncorrelated.

This lack of clear correlation may be explained, in part, by the different pathways of conversions between the different steroid hormones and the disturbance that may occur in the transport system between the tumor tissue and the circulation.

Thijssen et al. [41] previously tested the hypothesis of increased activity of aromatase enzyme in breast tumor tissues and found that the tumor enzymatic activity 
(expressed per gram of tissue) was high which could result in accumulation of some estrogen hormones in the malignant tissue. These findings may also explain the obtained increased tumor tissue estrogen levels.

In conclusion, it seems that there is a complicated system of pathways and interconversions between the sex steroid hormones within the breast tumor tissue that might be reflected in an increased or decreased level of one or more of them, at the expense of the others. Accordingly, if there exists an efficient system of transport, the changes may be reflected in the circulation of the patient. More information concerning this system of interconversion and its controlling conditions is needed to have a clear understanding of the role of these steroid hormones in breast cancer.

\section{References}

[1] G. Borsellino, A. Buonaquidi, M. Baroni, G. Elli, A. Sonato, S Rescalli and R. Monadina, Plasma steroid transport in subjects with tumors of hormonal target organs: a review, Tumori 78(3) (1992), 155-158.

[2] T.J. Key, Hormones and cancer in humans, Mutat Res 333(12) (1995), 59-67.

[3] J. Szymczak, A. Milewicz, J.H. Thijssen, M.A. Blankstein and J. Daroszewski, Concentration of sex steroids in adipose tissue after menopause, Steroids 63(5-6) (1998), 319-321.

[4] L. Bernstein, R.K. Ross, M.C. Pike, J.B. Brown and B.E. Henderson, Hormone levels in older women: A study of postmenopausal breast cancer patients and healthy controls, $\mathrm{BrJ}$ Cancer 61 (1990), 298-302.

[5] J.S. Meyer and M. Province, Proliferative index of breast carcinoma by thymidine labeling: prognostic power independent of stage, estrogen and progesterone receptors, Breast cancer Res treat 12 (1988), 191-204.

[6] G. Soderqvist, Effects of sex steroids on proliferation in normal mammary tissue, Ann Med 30(6) (1998), 511-524.

[7] R. Grattarola, G. Secreto and C. Recchino, Androgens in breast cancer. II. Endometrial adenocarcinoma and breast cancer in married postmenopausal women, Am J Obstet Gynecol 118 (1974), 173-178.

[8] G. Secreto, P. Toniolo and F. Berrino et al., Serum and urinary androgens and risk of breast cancer in postmenopausal women, Cancer Res 51 (1991), 2572-2576.

[9] G. Secreto and B. Zumoff, Abnormal production of androgens in women with breast cancer. (Review), Anticancer Res 14 (1994), 2113-2117.

[10] J.M. Gordin, P.K. Siiteri and P.C. McDonalds, Source of estrogen production in postmenopausal women, J Clin Endocrin Metab 36 (1973), 307-311.

[11] B.E. Henderson, R.K. Ross and M.C. Pike, Hormonal chemoprevention of cancer in women, Science 259 (1993), 633-638.

[12] P.K. Siiteri, G.L. Hammond and J.A. Nisker, Increased availability of serum estrogens in breast cancer: a new hypothesis, in: Banbury report 8, M.C. Pike, P.K. Siiteri and C.W. Welsh, eds, Cold Spring Harbor, NY, 1981, pp. 87-101.

[13] A. Zeleniuch-Jacquotte, P.F. Bruning and J. Bonfrer et al., Relation of serum levels of Testosterone and Dehydroepiandros- terone Sulfate to risk of breast cancer in postmenopausal women, Am J Epidem 145(11) (1997), 1030-1038.

[14] J.R. Pasqualini, Role of Androgens in breast cancer, J steroid Biochem Mol Biol 45(1-3) (1993), 167-172.

[15] P.E. Lonning, S.I. Helle and D.C. Johannessen et al., Relation between sex hormone binding globulin, insulin-like growth factor binding protein-1 in postmenopausal breast cancer patients, Clin Endocrinol (Oxford) 42 (1995), 23-30.

[16] J.F. Dorgan, C. Longcope, H.E. Stephenson, R.T. Falk and R. Miller et al., Serum sex hormone levels are related to breast cancer in postmenopausal women, Environ Health Perspect 105(3) (1997), 583-585.

[17] H.V. Thomas, T.J. Key, D.S. Allen, J.W. Moor, M. Dowsett and I.S. Fentiman et al., A prospective study of endogenous serum hormone concentrations and breast cancer risk in postmenopausal women on the island of Guernsey, Br J Cancer 76 (1997), 401-405.

[18] C. Longcope, C. Franz, C. Morello, R. Baker and C.C. Johnston, Steroid and gonadotropin levels in women during the peri-menopausal years, Maturitas 8 (1986), 189-196.

[19] K.D. Roberts, J.G. Rochefort, G. Bleau and A. Chapdelaine, Plasma estrone sulfate levels in postmenopausal women, Steroids 35 (1980), 170-187.

[20] J.A. Cauley, F.L. Lucas, L.H. Kuller, K. Stone, W. Browner and S.R. Cummings, Elevated serum estradiol and testosterone concentrations are associated with a high risk of breast cancer. Study of Osteoporotic Fractures Research Group, Ann Intern Med 130(4 pt 1) (1999), 270-277.

[21] F. Berrino, P. Muti, A. Micheli, G. Bolelli and V. Krogh et al., Serum sex hormone levels after menopause and subsequent breast cancer, J Natl Cancer Inst 88(5) (1996), 291-296.

[22] M. Grimaux, E. Mady, C. Laine-Bidron and H. Magdelenat, A simplified immunoenzymetric assay of epidermal growth factor receptor in breast tumors. Evaluation in 282 cases, Int J Cancer 45 (1990), 255-262.

[23] U. Raju, S. Banerjee and M. Levitz et al., Correlation of concentrations of estriol-3-sulfate with those of potassium and sodium in human breast cyst fluid, Steroids 45 (1985), 341346.

[24] U. Raju, H.L. Bradlow and M. Levitz, Estriol-3-sulfate in human breast cyst fluid: concentrations, possible origin and physiologic implications, Ann NY Acad Sci 586 (1990), 83-87.

[25] J.R. Pasquilini, B. Schatz, C. Varin and B.L. Nguyen, Recent data on estrogen sulfatases and sulfotransferases activities in human breast cancer, J steroid Biochem Mol Biol 41 (1992), 323-329.

[26] J.F. Dorgan, C. Longcope, H.E. Stephenson, R.T. Falk, R. Miller and C. Franz et al., Relation of prediagnostic serum estrogen and androgen levels to breast cancer risk, Cancer Epidemiol Biomarkers Prev 5 (1996), 533-539.

[27] J. Pasquilini, G. Chetriten, C. Blacker, M.C. Feinstein, L. Delalonde, M. Talbi and C. Maloche, Concentrations of estrone, estradiol and estrone sulfate and evaluation of sulfatase and aromatase activities in pre- and postmenopausal breast cancer patients, J Clin Endocrinol Metabol 81(4) (1996), 1460-1464.

[28] M.G. Reed, R.W. Cheng and C.T. Noel, Plasma levels of estrogen, estrogen sulfate and estradiol and the percentage of unbound estradiol in postmenopausal women with and without breast diseases, Cancer Res 43 (1983), 3940-3945.

[29] D.K. Wysowski, G.W. Comstock, K.J. Helsing and H.L. Lau, Sex hormone levels in serum in relation to the development of breast cancer, Am J Epidemiol 25 (1987), 791-794.

[30] R.R. Mehta and J.M. Graves, Breast tumor-derived factors 
stimulate reduction of estrone to estradiol in nonmalignant breast tissue, Breast Cancer Res Treat 23(1-2) (1992), 51-56.

[31] S.E. Hankinson, W. Willett, J.E. Manson, A. Graham, C.D. Hunter, D. Spiegelman, R.L. Barbieri and F.E. Speizer, Plasma sex steroid hormone levels and risk of breast cancer in postmenopausal women, J Natl Cancer Inst 90(17) (1998), 12921299.

[32] B. Lippman, G. Bolan and K. Huff, The effects of androgens and antiandrogens on hormone-responsive human breast cancer in long-term tissue culture, Cancer Res 36 (1976), 46104618.

[33] V.H. James, J.M. McNeil, C. Lai, C.J. Newton, M.W. Ghilchik and M.J. Reed, Aromatase activity in normal breast and breast tumor tissues: in vivo and in vitro studies, Steroids $\mathbf{5 0}$ (1987), 269-279.

[34] J.H. Thijssen, M.A. Blankenstein, W.R. Miller and A. Milewicz, Estrogens in tissues: uptake from the peripheral circulation or local production, Steroids 50 (1987), 297-306.

[35] L. Bernstein and R.K. Ross, Endogenous hormones and breast cancer risk, Epidemiol Rev 15 (1993), 48-65.

[36] A.A. Van Landeghem, J. Poortman, M. Nabuurs and J.H. Thijssen, Endogenous concentration and subcellular distribution of estrogens in normal and malignant human breast cancer tissue, Cancer Res 45 (1985), 2900-2906.

[37] J.H. Thijssen and M.A. Blankenstein, Endogenous estrogens and androgens in normal and malignant endometrial and mammary tissues, Eur J Cancer Clin Oncol 25 (1989), 1953-1959.

[38] A. Vermeulen, J.P. Deslypere, R. Paridaens, G. Leclercq, F. Roy and J.C. Heuson, Aromatase 17B-hydroxysteroid dehydrogenase and intra-tissular sex hormone concentrations in cancerous and normal glandular breast tissue in postmenopausal women, Eur J Cancer Clin Oncol 22 (1986), 515525.

[39] E. Perel, M.E. Blackstein and D.W. Killinger, Aromatase in human breast carcinoma, Cancer Res 42(8) (1982), 3369s3372s.

[40] M.J. Iqbal, S.H. Valyani and J.V. Roberts, Mechanism of sexsteroid accumulation in the etiology of human breast carcinoma: the role of intracellular sex hormone binding globulin, Anticancer Res 8 (1988), 479-481.

[41] J.H. Thijssen, M.A. Blankenstein, G.H. Donker and J. Daroszewski, Endogenous steroid hormones and local aromatase activity in the breast, J Steroid Biochem Mol Biol 39 (1991), 799-804. 
Table 3

Serum levels of Estrone $\left(E_{1}\right)$, Estrone Sulfate $\left(E_{1} S\right)$, Estradiol $\left(E_{2}\right)$, Estriol $\left(E_{3}\right)$, and Testosterone $(T)$ in patients with benign and malignant breast tumors

\begin{tabular}{|c|c|c|c|c|c|c|c|c|c|c|c|c|c|c|c|}
\hline \multirow[t]{2}{*}{ Variable } & \multicolumn{3}{|c|}{$\begin{array}{l}\mathrm{E}_{1}(\mathrm{Pmole} / \mathrm{ml}) \\
(\text { Mean } \pm \mathrm{SE})\end{array}$} & \multicolumn{3}{|c|}{$\begin{array}{c}\mathrm{E}_{1} \mathrm{~S}(\mathrm{Pmole} / \mathrm{ml}) \\
(\text { Mean } \pm \mathrm{SE})\end{array}$} & \multicolumn{3}{|c|}{$\begin{array}{c}\mathrm{E}_{2}(\mathrm{Pmole} / \mathrm{ml}) \\
(\text { Mean } \pm \mathrm{SE})\end{array}$} & \multicolumn{3}{|c|}{$\begin{array}{c}\mathrm{E}_{3}(\mathrm{Pmole} / \mathrm{ml}) \\
(\text { Mean } \pm \mathrm{SE})\end{array}$} & \multicolumn{3}{|c|}{$\begin{array}{l}\mathrm{T}(\text { Pmole/ml) } \\
(\text { Mean } \pm \mathrm{SE})\end{array}$} \\
\hline & Benign & Malignant & $P^{*}$ & Benign & Malignant & $P$ & Benign & Malignant & $P$ & Benign & Malignant & $P$ & Benign & Malignant & $P$ \\
\hline Premenopausal & & & & & & & & & & & & & & & \\
\hline Follicular phase & $0.118 \pm 0.01$ & $0.311 \pm 0.04$ & 0.05 & $3.4 \pm 1.1$ & $4.8 \pm 0.57$ & 0.57 & $0.136 \pm 0.01$ & $0.29 \pm 0.02$ & 0.05 & $2.6 \pm 0.03$ & $2.88 \pm 0.07$ & 0.15 & $8.33 \pm 0.7$ & $2.15 \pm 0.34$ & 0.001 \\
\hline Luteal phase & $0.133 \pm 0.03$ & $0.303 \pm 0.03$ & 0.05 & $3.4 \pm 0.6$ & $5.4 \pm 0.57$ & 0.29 & $0.117 \pm 0.01$ & $0.228 \pm 0.02$ & 0.04 & $2.56 \pm 0.1$ & $3.26 \pm 0.1$ & 0.04 & $5.2 \pm 0.1$ & $0.67 \pm 0.14$ & 0.05 \\
\hline Postmenopausal & $0.137 \pm 0.02$ & $0.167 \pm 0.02$ & 0.33 & $2.6 \pm 0.6$ & $0.91 \pm 0.05$ & 0.02 & $0.132 \pm 0.01$ & $0.143 \pm 0.01$ & 0.49 & $2.95 \pm 0.1$ & $3.02 \pm 0.03$ & 0.78 & $5.89 \pm 0.5$ & $1.77 \pm 0.14$ & 0.005 \\
\hline
\end{tabular}

Table 4

Cytosol levels of Estrone $\left(E_{1}\right)$, Estrone Sulfate $\left(E_{1} S\right)$, Estradiol $\left(E_{2}\right)$, Estriol $\left(E_{3}\right)$, and Testosterone $(T)$ in patients with benign and malignant breast tumors

\begin{tabular}{|c|c|c|c|c|c|c|c|c|c|c|c|c|c|c|c|}
\hline \multirow[t]{2}{*}{ Variable } & \multicolumn{3}{|c|}{$\begin{array}{l}\mathrm{E}_{1}(\text { Pmole/g) } \\
(\text { Mean } \pm \text { SE) }\end{array}$} & \multicolumn{3}{|c|}{$\begin{array}{c}\mathrm{E}_{1} \mathrm{~S}(\mathrm{Pmole} / \mathrm{g}) \\
(\mathrm{Mean} \pm \mathrm{SE})\end{array}$} & \multicolumn{3}{|c|}{$\begin{array}{l}\mathrm{E}_{2}(\text { Pmole/g) } \\
(\text { Mean } \pm \mathrm{SE})\end{array}$} & \multicolumn{3}{|c|}{$\begin{array}{l}E_{3}(\text { Pmole/g) } \\
(\text { Mean } \pm \text { SE) }\end{array}$} & \multicolumn{3}{|c|}{$\begin{array}{c}\mathrm{T}(\text { Pmole/g) } \\
(\text { Mean } \pm \text { SE) }\end{array}$} \\
\hline & Benign & Malignant & $P^{*}$ & Benign & Malignant & $P$ & Benign & Malignant & $P$ & Benign & Malignant & $P$ & Benign & Malignant & $P$ \\
\hline Premenopausal & & & & & & & & & & & & & & & \\
\hline Follicular phase & $18.9 \pm 0.09$ & $20.1 \pm 0.8$ & 0.56 & $37.1 \pm 0.6$ & $36.8 \pm 0.3$ & 0.67 & $5.23 \pm 0.01$ & $5.3 \pm 0.23$ & 0.29 & $27.7 \pm 0.7$ & $25.3 \pm 0.38$ & 0.29 & $13.8 \pm 1.0$ & $10.3 \pm 1.0$ & 0.4 \\
\hline Luteal phase & $15.1 \pm 0.69$ & $17.6 \pm 0.7$ & 0.25 & $36.8 \pm 0.6$ & $35.7 \pm 1.4$ & 0.52 & $4.53 \pm 0.11$ & $4.63 \pm 0.26$ & 0.36 & $26.6 \pm 0.6$ & $25.6 \pm 0.69$ & 0.63 & $7.89 \pm 0.24$ & $9.02 \pm 0.69$ & 0.1 \\
\hline Postmenopausal & $12.4 \pm 0.49$ & $18.6 \pm 0.4$ & 0.003 & $36.8 \pm 0.3$ & $37.4 \pm 0.1$ & 0.42 & $3.99 \pm 0.17$ & $4.6 \pm 0.09$ & 0.21 & $29.4 \pm 0.3$ & $26 \pm 0.18$ & 0.004 & $6.94 \pm 1.0$ & $11.4 \pm 1.0$ & 0.005 \\
\hline
\end{tabular}




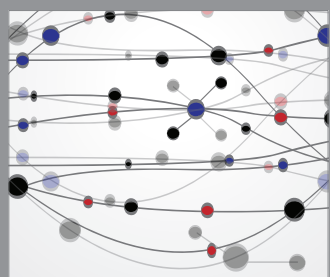

The Scientific World Journal
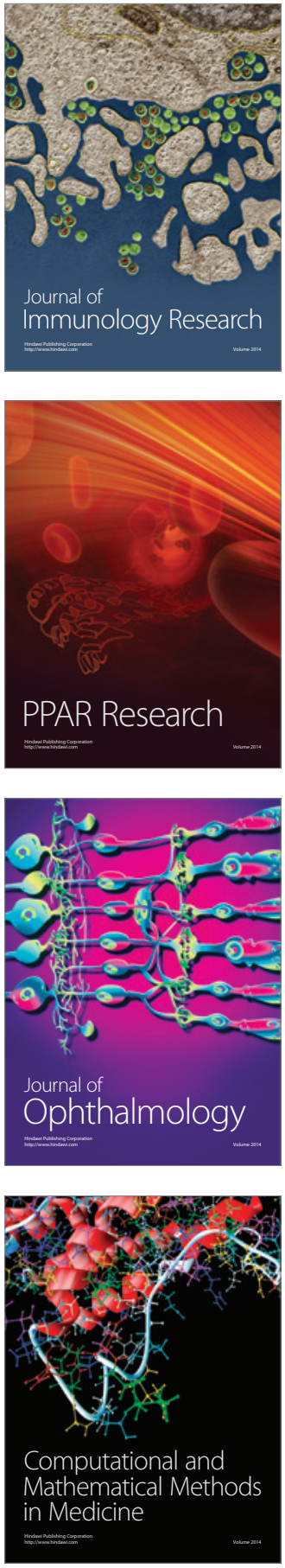

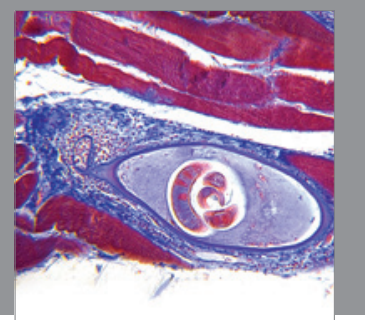

Gastroenterology

Research and Practice
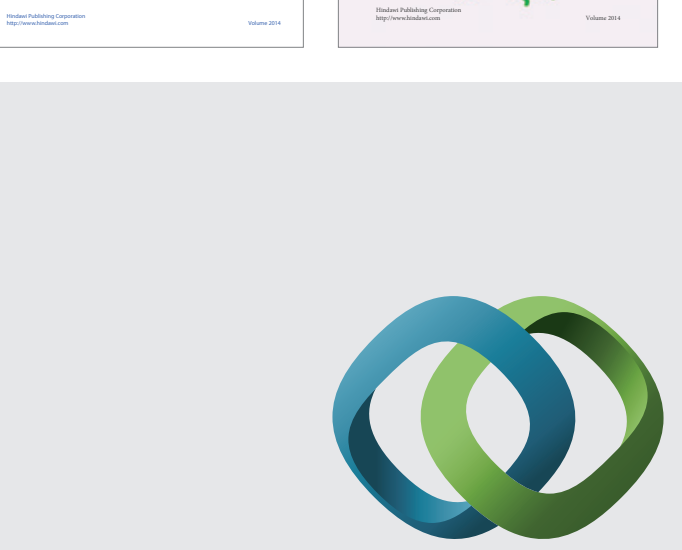

\section{Hindawi}

Submit your manuscripts at

http://www.hindawi.com
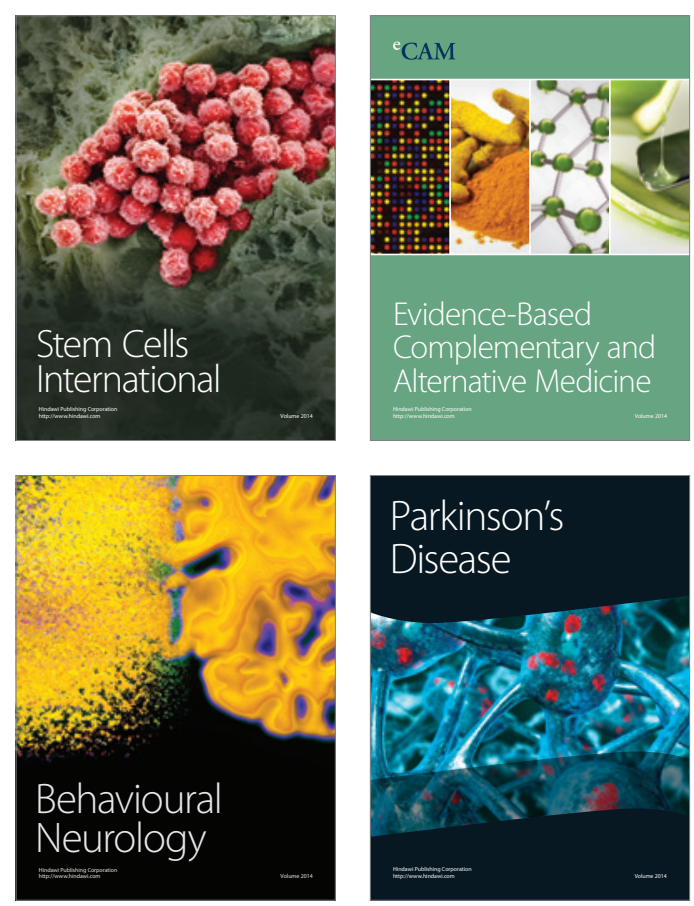

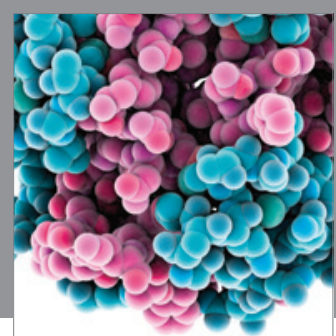

Journal of
Diabetes Research

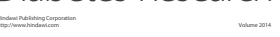

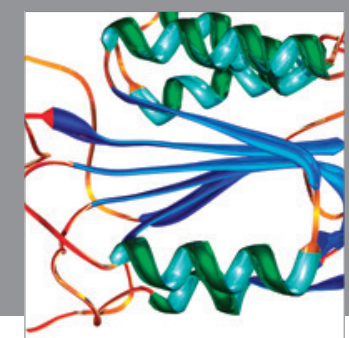

Disease Markers
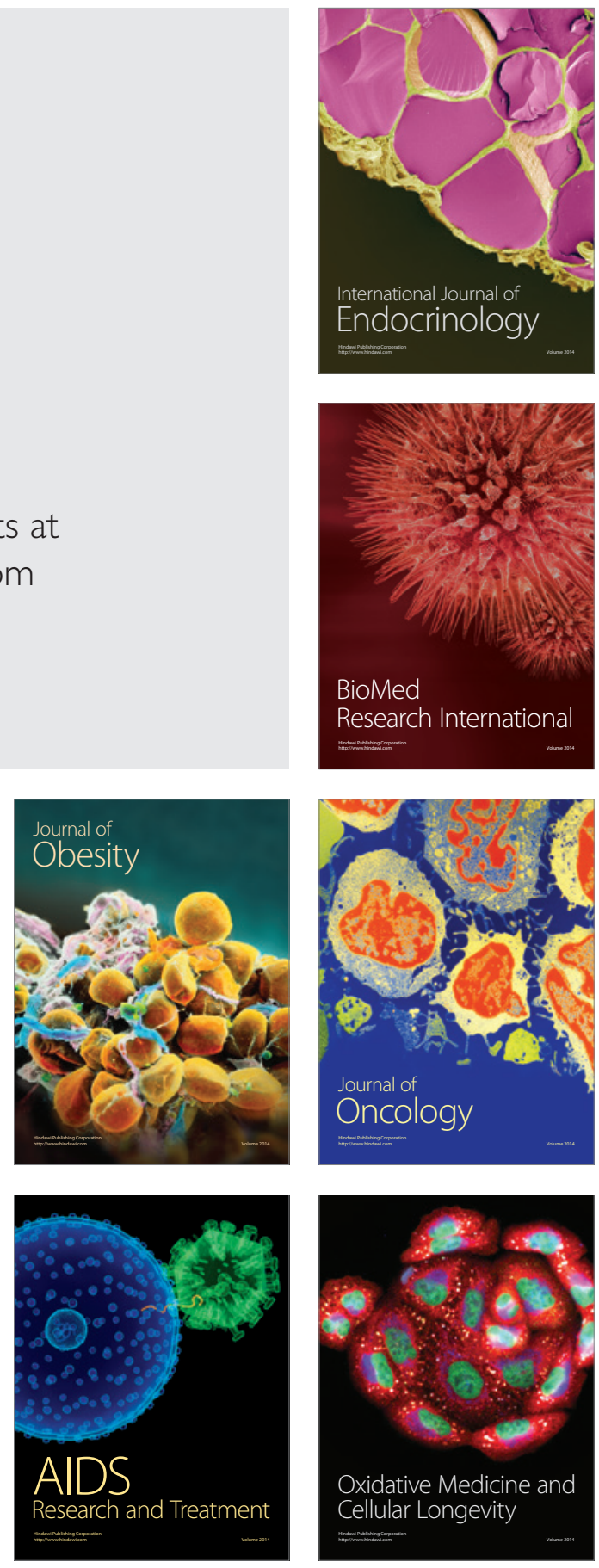